\title{
Oxidative DNA Damage Protective Ability of Punica granatum
}

\author{
Bircan ÇEKEN TOPTANCI ${ }^{1}$
}

ABSTRACT: Oxidative stress can cause harm to macromolecules such as lipid, protein and DNA. Therefore, there has been a huge attention to find out organic sources with antioxidant properties to prevent oxidative stress-induced damage. Literature data on this subject have suggested that consuming food which contain phenolic compounds decreases the risk of several diseases and protection against certain forms of cancer. Punica granatum L., known as pomegranate belongs to the family Punicacea. It is one of the fundemantel fruit, cultivated in Mediterranean countries. The present study was designed to investigate the total phenolic content of the Derik pomegranate peel and juice, and their protective ability against DNA damage induced by Fenton System. The result indicates that both juice and peel have a significant protective effect on oxidative DNA damage.

Keywords: DNA damage, phenolic compounds, Punica granatum.

\section{Oksidatif DNA Hasarına Karşı Punica granatum'un Koruyucu Etkisi}

ÖZET: Oksidatif stres lipid, protein ve DNA'ya zarar verebilir. Bundan dolayı antioksidant özellik gösteren organik kaynakların, oksidatif stres sonucu oluşan hasarları önleme özelliklerinin, ortaya çıkartılması oldukça dikkat çekmiştir. Yüksek fenolik bileşik içeren yiyeceklerin birçok hastalık riskini azalttığı ve bazı kanser türlerine karşı koruyucu etkilerinin olduğu literatürde yer almıştır. Nar olarak bilinen Punica granatum L. Punicacea familyasına aittir. Oldukça önemli ve eskiden beri tüketilen bir meyve olan nar başlıca Akdeniz ülkelerinde üretilmektedir. Bu çalışmada ilk defa Derik nar suyu ve kabuğunun fenolik içeriği ve bunların fenton sistemi ile oluşturulan oksidatif DNA hasarına karşı koruma etkisi incelendi. Sonuç olarak, nar suyu ve kabuğunun DNA'da meydana gelen hasara karşı koruyucu etki gösterdiği belirlendi.

Anahtar Kelimeler: DNA hasarı, fenolik bileşikler, Punica granatum.

1 Bircan ÇEKEN TOPTANCI (0000-0002-9578-3786), Dicle Üniversitesi, Fen Fakültesi, Kimya/Biyokimya, Diyarbakır, Türkiye Sorumlu yazar/Corresponding Author: Bircan ÇEKEN TOPTANCI, bircan@dicle.edu.tr 


\section{INTRODUCTION}

Reactive oxygen species (ROS) react very fast with biomolecules such as lipid, carbohydrate, protein, RNA and DNA in the living organism, resulting in tissue injury, cell damage or gene mutation (Farber, 1994). The antioxidants contained in diets based on fruit and vegetables, such as vitamins, carotenoids, flavonoids and phenolic compounds mainly tannins, are believed to play a very great effect to provide protection against those oxidative damages (Macheix and Fleuriet, 1990). Therefore, the attention is now paid to the develop an effective antioxidants, especially the wild type of natural plants used in folk medicine and food.

Pomegranate contains valuable antioxidant compounds and has been used broadly in the herbal remedies. This fruit cultivated in Mediterranean countries, Iran, Turkey, India, Afghanistan, United States, Russia, Japan and China (Patil and Karale, 1990). The fruit is used alone or processed into jam, wine and sauce. The fruit may also be used decoration agent and as cattle feed due to their richness in fibre and antioxidants.

The chemical content of pomegranate depends on climate, cultivar type, growing region, cultural practice, storage and processing factors. Turkey is one of the endemic fields of the pomegranate, which has spread, and is grown in many areas. The total production of this product in Turkey was 376000 tons in 2014 according to Turkish Statistical Institute 2015 (Kahramanoglu and Usanmaz, 2016).

In Turkey, various pomegranate cultivars are available with a different aroma, taste or color. Hicaz nar, Çekirdeksiz VI, Silifke Aşısı, Katırbaşı, Lefan, Ekşi, Kan, şerife, Dikenli incekabuk and Tatli are some of the most important varieties which are cultivated in the country (Gozlekci et al., 2011).

Derik pomegranate is another important variety cultivated in Turkey. This variety belongs to Derik, Mardin. It is rind and colour is pink. The taste is sour and the seed toughness is soft. Derik pomegranate juice also exhibits good phenolic and flavonoid contents and showed protective ability against carbon tetrachloride exposure in rats (Pirinccioglu et al., 2014). However, no studies have been reported on the protective ability of pomegranate juice and peel extract on DNA damage. Therefore, current work was designed to identify the phenolic content of Derik pomegranate juice, peel extract and to test their ability against DNA damage caused by ROS.

\section{MATERIALS AND METHODS}

\section{Plant Material}

Pomegranate (Punica granatum L) was provided in Derik, Mardin, Turkey in November, 2012.

\section{Preparation of pomegranate juice}

The juice was prepared as described by Pirinccioğlu et al (2014). The concentrated pomegranate juice was diluted 1:1, 1:2 and 1:3 $\left(\mathrm{v} \mathrm{v}^{-1}\right)$ with water.

\section{Preparation of pomegranate peel extract}

Fruits $(2 \mathrm{~kg})$ were cleaned by top water and then peeled. The peels were air dried in an oven at $40{ }^{\circ} \mathrm{C}$ for $48 \mathrm{~h}$. Then, the material $(233.57 \mathrm{~g})$ ground to a powder. Powdered material (100 g) was extracted with ethanol $(800 \mathrm{~mL})$ for $24 \mathrm{~h}$ in shaking water bath at room temperature (Shan et al., 2009). Sample was then filtered, freeze-dried and stored in refrigerator at $4{ }^{\circ} \mathrm{C}$.

\section{Total Phenolics Contents}

Folin-Ciocalteau method were used for determination of phenolic yields in both juice and peel samples (Singleton et al., 1999). Results were expressed as $\mu \mathrm{g}$ of gallic acid equivalents per $1 \mathrm{mg}$ of peel extract or $1 \mathrm{ml}$ of juice sample.

\section{DNA Damage Protective Ability}

The protective ability of pomegranate juice and peel extract against DNA damage induced by Fenton System was determined by agarose gel electrophoresis according to Kizil et al (2009).

\section{Densitometric analysis}

Gel documentation system was used for scanning to the gel (Gel-Doc-XR; BioRad) and Quantity One programme was used for quantifying bands on the gels (version 4. 5. 2, BioRad).

Table. Total phenolics content of pomegranate juice and peel extract

\begin{tabular}{ccc}
\hline Sample & $\begin{array}{c}\text { Juice } \\
\left(\mu \mathrm{g} \mathrm{GAE} \mathbf{~ m L}^{-1} \text { juice }\right)\end{array}$ & $\begin{array}{c}\text { Peel } \\
\left(\mu \mathrm{g} \text { GE } \mathbf{g}^{-1} \text { peel }\right)\end{array}$ \\
\hline & $3170 \pm 188$ & $430.0 \pm 22.0$ \\
\hline
\end{tabular}




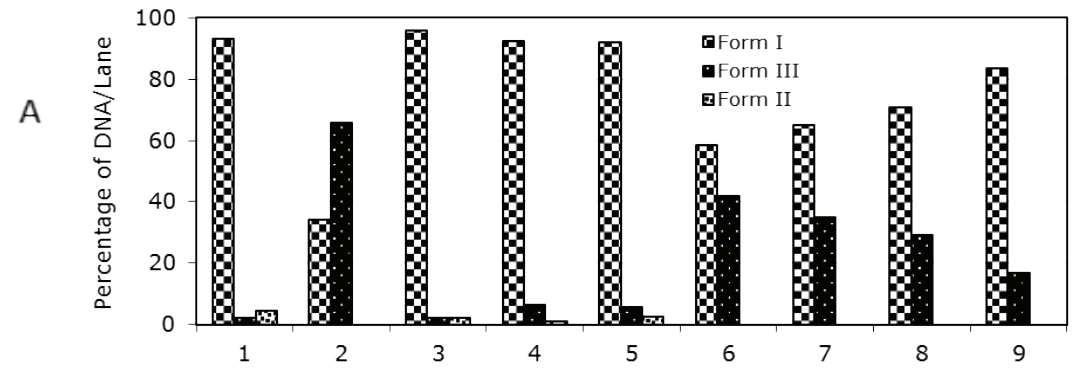

B

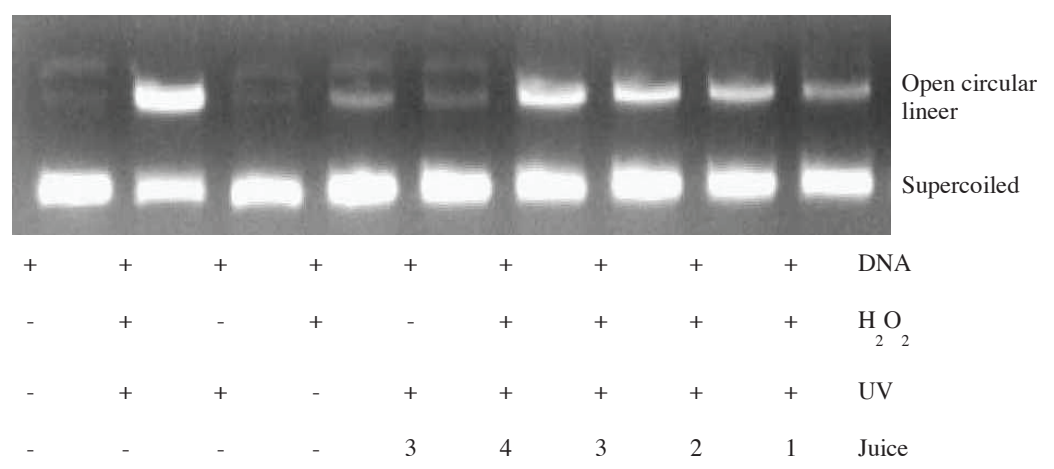

1 ; concentrated juice

2; diluted with water (juice:water, 1:1)

3; diluted with water (juice:water, 1:2)

4; diluted with water (juice:water, 1:3)

Figure 1. Intensity of the quantified band for the supercoiled, open circular and lineer DNA (A). Gel electrophoresis diagram showing DNA damage protective ability of supercoiled DNA (3.2 kb, $200 \mathrm{ng})$ by pomegranate juice (B).

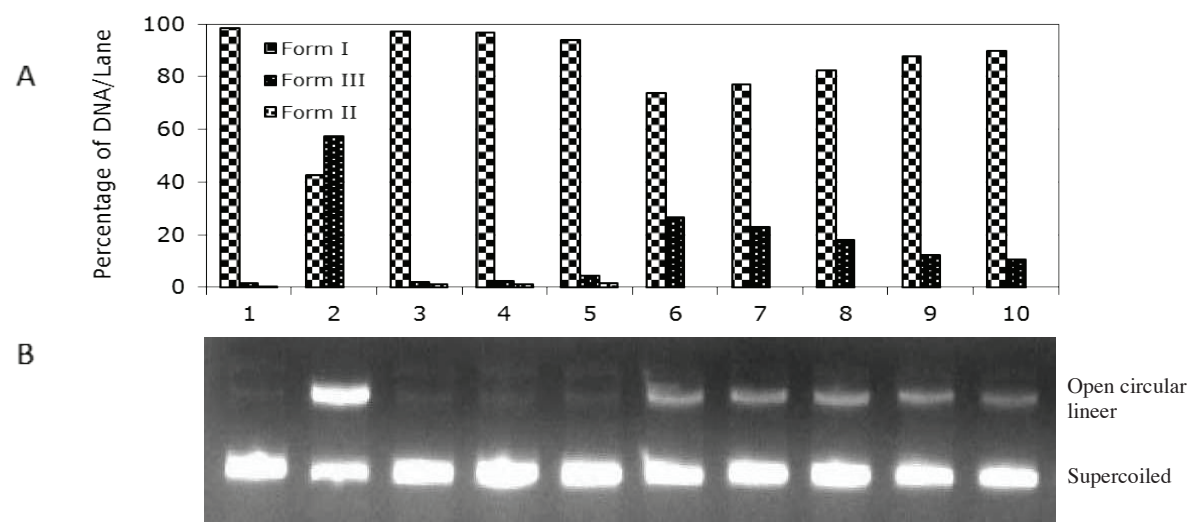

damage protective ability of supercoiled DNA $(3.2 \mathrm{~kb}, 200 \mathrm{ng})$ by pomegranate peel extract (B). 


\section{RESULTS AND DISCUSSION}

Oxidative stress can cause multiple cellular disorders via lipid peroxidation, protein and DNA damage resulting several chronic human diseases (Uttara et al., 2009). Disorders can be delayed or prevented with plant derived natural antioxidants like polyphenolic compounds. Therefore, many scientific studies are focused on exploring cheap, safe, natural and effective plants or fruits with antioxidant potential (Lobo et al., 2010).

Pomegranate fruit has become more attractive because of the attribution of important biological actions. Researchers have showed that pomegranate and its derivatives have potent antioxidant activity (Gil et al., 2000; Vernet et al., 2004; Rosenblat et al., 2006).

In the literature, different Turkish pomegranate cultivars were investigated and their phenolic contents were identified (Çam et al., 2009). In this study Derik pomegranate cultivar also showed high phenolic content. Table 1 shows the total phenolic yield of pomegranate juice and peel extract. In the present work, the total phenolic yield of Derik pomegranate juice was found to be $3170 \pm 188.0$ $\mu \mathrm{g}$ GAE $\mathrm{mL}^{-1}$ and peel extract was determined to be $430.0 \pm 22.0 \mu \mathrm{g} \mathrm{GAE} \mathrm{mg}^{-1}$. In Our previous data, the amount of total phenolic of same fruit juice were detected as $3501 \pm 282.4 \mu \mathrm{g} \mathrm{GAE} \mathrm{mL} L^{-1}$ juice. There is not any significant difference between those tested samples in different years. This confirms that Derik pomegranate cultivars stable for phenolic content. It is known that in some fruits the discarded part can be a serious waste disposal problem. There are a several possibilities for use of some types of fruit wastes, because the outer skins of fruit and vegetables are filled with flavor and vitamins. Antioxidant activities of different fruit waste extracts were studied (Heber et al., 2006; Li et al., 2006; Okonogi et al., 2007). Pomegranate is contain polyphenols. Phenolics in fruits mainly responsible its antioxidant activity. This work suggested that freeze-dried Derik pomegranate peel may used as an antioxidant candidate for food and pharmaceutical industries.

Oxidative DNA damage in biological systems usually caused by hydroxyl radical. Phenolics and flavonoids from vegetables can scavenge hydroxyl radicals. In this experiment, the capacity of the pomegranate juice and peel extracts for protection oxidative DNA damage was compared against DNA cleavage to pBluescript plasmid DNA by hydroxyl radical generated in the fenton reaction. Figure 1 and 2 shows the DNA damage protective ability of pomegranate juice and peel extract, respectively. The juice was diluted 1:1, 1:2 and 1:3 $\left(\mathrm{v} \mathrm{v}^{-1}\right)$ to measure its DNA damage protective activity. It was reduced the formation of lineer form of DNA (Figure 1; lane 6-9). Similar to juice, peel extract (Figure 2; lane $6-10 ; 100-500 \mu \mathrm{g} \mathrm{mL}^{-1}$ ) was also found to be able to reduce the formation of lineer form. Supercoiled DNA was partially protected by pomegranate in a concentration dependent manner.The result indicates that both juice and peel have a significant protective effect on supercoiled DNA.

When the level of DNA damage is high, this damage can exceed the cellular repair mechanisms and resulting in mutations and apoptosis. The findings suggested that the juice and peel extract of Derik pomegranate displayed protective effect against DNA damage.

\section{CONCLUSION}

Pomegranate, the member of the Punicaceae family, is an important fruit and has been known since antiquity, with mystical properties. In many religious books, pomegranate is shown as a symbol of luck, abundance and productivity. Pomegranate has been used as a healing tool for various diseases in ancient times. It is also known as 'pharmacy plant' in Ayurveda medicine, and used in the treatment of aphthae, diarrhea, ulcer and parasitosis.

The present study is carried out to investigate the total phenolic content of Derik pomegranate peel and juice, and their protective ability against DNA damage induced by Fenton System.

In conclusion pomegranate have a great potential as a food supplement to prevent some of the disorders caused by oxidative stress. 


\section{REFERENCES}

Çam M, Hışıl Y, Durmaz G, 2009. Classification of eight pomegranate juices based on antioxidant capacity measured by four methods. Food Chemistry, 112(3):721-726.

Farber JL 1994. Mechanisms of cell injury by activated oxygen species. Environmental health perspectives, 102 (10):17-24.

Gil MI, Tomás-Barberán FA, Hess-Pierce B, Holcroft DM, Kader AA, 2000. Antioxidant ctivity of pomegranate juice and its relationship with phenolic composition and processing. Journal of Agricultural and Food Chemistry, 48(10):4581-4589.

Gozlekci S, Saracoglu O, Onursal E, Ozgen M, 2011. Total phenolic distribution of juice, peel, and seed extracts of four pomegranate cultivars. Pharmacognosy Magazine, 7(26):161-164.

Heber D, Schulman RN, Seeram NP, 2006. Pomegranates: ancient roots to modern medicine. CRC press/Taylor \& Francis, Boca Raton, $244 \mathrm{p}$.

Kahramanoglu I, Usanmaz S, 2016. Pomegranate Production and Marketing. CRC Press, Boca Raton, 148 p.

Kızıl G, Kızıl M, Çeken B, 2009. Protective ability of ethanol extracts of Hypericum scabroides Robson \& Poulter and Hypericum triquetrifolium Turra against protein oxidation and DNA damage. Food Science and Biotechnology, 18(1):130-136.

Li Y, Guo C, Yang J, Wei J, Xu J, Cheng S, 2006. Evaluation of antioxidant properties of pomegranate peel extract in comparison with pomegranate pulp extract. Food Chemistry, 96(2):254260.

Lobo V, Patil A, Phatak A, Chandra N, 2010. Free radicals, antioxidants and functional foods: Impact on human health. Pharmacognosy Reviews, 4(8):118.

Macheix J-J, Fleuriet A, 1990. Fruit Phenolics. CRC press, Boca Raton, 378 p.
Okonogi S, Duangrat C, Anuchpreeda S, Tachakittirungrod S, Chowwanapoonpohn S, 2007. Comparison of antioxidant capacities and cytotoxicities of certain fruit peels. Food Chemistry 103(3):839-846

Patil A, Karale A, 1990. Pomegranate. Fruits: Tropical and subtropical, CRC press/Taylor \& Francis, Boca Raton, 614 p.

Pirinccioglu M, Kizil G, Kizil M, Kanay Z, Ketani A, 2014. The protective role of pomegranate juice against carbon tetrachloride-induced oxidative stress in rats. Toxicology and Industrial Health, 30(10):910-918.

Rosenblat M, Hayek T, Aviram M, 2006. Anti-oxidative effects of pomegranate juice (PJ) consumption by diabetic patients on serum and on macrophages. Atherosclerosis, 187(2):363-371.

Shan B, Cai YZ, Brooks JD, Corke H, 2009. Antibacterial and antioxidant effects of five spice and herb extracts as natural preservatives of raw pork. Journal of the Science of Food and Agriculture, 89(11):1879-1885.

Singleton VL, Orthofer R, Lamuela-Raventos RM, 1999. Analysis of total phenols and other oxidation substrates and antioxidants by means of folin-ciocalteu reagent. Methods in Enzymology, 299:152-178.

Uttara B, Singh AV, Zamboni P, Mahajan R, 2009. Oxidative stress and neurodegenerative diseases: a review of upstream and downstream antioxidant therapeutic options. Current Neuropharmacology, 7(1):65-74.

Vernet P, Aitken R, Drevet J, 2004. Antioxidant strategies in the epididymis. Molecular and Cellular Endocrinology, 216(1):3139. 